\title{
The Relationship between Innovative Work Behaviors and Subjective Career Success among Employees in Selected Private Organisation
}

\author{
Nur Fatihah Abdullah Bandar, Fatin Adibah binti Malek, Zaiton Hassan, Surena Sabil, Dayang \\ Kartini Abang Ibrahim, Nik Norsyamimi binti Md Nor, Rekaya Vincent Balang
}

\begin{abstract}
Innovations are crucial factors in enabling organisations to effectively adapt to rapid changes in the working environment and to gain a competitive advantage. Employee's career success increases when they are applying innovative work behaviors. This study attempts to examine the relationship between innovative work behaviors (opportunity exploration, idea generation, idea promotion, idea realisation \& reflection) and subjective career success among employees in selected private organisations at Kuching, Sarawak. A quantitative research design was utilized for this study. Data were collected by simple random sampling with 123 completed questionnaire were successively collected. The findings of this study were analysed using Pearson Correlation Analysis and Multiple Linear Regression (Stepwise). Results revealed that there are statistically significant relationship between(opportunity exploration, idea generation, idea promotion, idea realisation \& reflection) and subjective career success. Furthermore, result show that idea realization is the highest significant predictor towards subjective career success. The findings of this study provide significant information for HRD practitioners emphasise to establish an environment that support innovation in order to make the greater experience of subjective career success.
\end{abstract}

Keywords : Innovative Work Behaviors, Subjective Career Success, Private Organisation

\section{INTRODUCTION}

Today, innovations are crucial factor in enabling organisations to effectively adapt to rapid changes in working environment and to gain a competitive advantage. Innovations are referred to novel and potentially useful

Revised Manuscript Received on September 22, 2019

* Correspondence Author

Dr. Nur Fatihah Abdullah Bandar*, Senior Lecturer, Faculty of Cognitive Sciences and Human Development, Human Resource Development Programme, Universiti Malaysia Sarawak. (Email: abnfatihah@unimas.my)

Fatin Adibah binti Malek, Pursuing Masters Degree, Human Resource Development, Universiti Malaysia Sarawak.

Dr. Zaiton Hassan, Associate Professor, Human Resource Development Program, Faculty of Cognitive Sciences and Human Development, Universiti Malaysia Sarawak, Malaysia.

Dr Surena Sabil,Senior Lecturer, Department of Human Resource, Faculty of Cognitive Sciences and Human Development, Universiti Malaysia Sarawak (UNIMAS).

Dayang Kartini binti Abang Ibrahim, Pursuing Ph.D, Human Resource Development,UPM.

Nik Norsyamimi binti Md Nor, University Lecturer, University of Malaysia Sarawak (UNIMAS).

Rekaya Vincent Balang, Senior Lecturer at Department of Nursing, Faculty of Medicine and Health Sciences, UNIMAS products or processes that are developed to address problems or improve the status quo of a particular work context. This includes rethinking and changing underlying principles of organisational work. Organisations are facing greater demand to engage in innovative work behaviors in order to sustain competitive and lead the change process itself [1].

Since organisations rely so much mainly on employees to innovate their processes, methods and operations, the contribution toward innovative development are necessary and expected from employees. Employee's contributions towards innovative development are referred as innovative work behaviors (IWB) which encompasses all work activities carried out in relation to the development of innovations [2]. Scholars also proposed that innovative work behaviors (IWB) were form from five interrelated sets of behavioral activities namely opportunity exploration, idea generation, idea promotion, idea realization and reflection. According to Dy Bunpin et al. [3], when employees engaged in innovative work behaviors, they can adopt positive attitudes and respond appropriately to collaborators, customers and managers. Hence, the necessity for organisations to nurture innovative mindsets among employees to deliver more value creation is crucial in order to sustain longer-term survival and success [4].

Prior study suggested that future researchers should test whether innovative work behaviors will influence career success [5]. Career success is defined as, "positive psychological or work-related outcomes or achievement one has accumulated as a result of one's work experiences" [3]. Although the study of career success has progressed significantly, most of career success research has been conducted mainly focusing in overseas region [6] - [12].

From the Malaysian perspectives, past studies on career success have mostly been associated with women and academicians [13] - [15]. There is a limited study focuses on the relationship between innovative work behaviors and subjective career success. As postulated by Dailey, Morris \& Hoge [16], employee's career success increase when they are applying innovative work behaviors. Hence, it is important for organisations and human resource development (HRD) practitioners to study the linkages between innovative work behaviors and career success.

\section{A. Problem Statement}

Social Cognitive Career Theory proposed that individuals exercise personal agency in their career development are conceived as a function of an individual's self-efficacy, outcome expectations, goals, and 
support or barriers in the environment [17]. Accordingly, in order to further support the nature of SCCT, Smale et al. [5] suggested that future research should focus on the other individual factors (personal agency) with the career development concept in the theory. Therefore, the study intended to extend SCCT in a comprehensive manner by exploring how contextual factors (innovative work behavior) interface with person inputs (such as predispositions) to shape the career success of private organisation's employees.

There are several empirical gaps that have been identified related to the present study. First, there has been an increasing amount of literatures focusing on innovative work behaviors in banking sector [18], government sector [19], and automotive sector [20]. Therefore, to address this gap the present study focuses on private construction company. Second, most of past studies related to career success focuses on the linkages between both dimensions of career success which are known as objective and subjective career success [21], [22].

Smale, et.al [5] indicate that individual factors also contributed to career success. Hence, the present study attempts to study the relationships between individual factor (innovative work behaviors) and subjective career success only. Finally, most of past innovative work behaviors studies focused on nurses [23], teachers [24] and vocational teachers [25]. Hence, the present study will extend to construction workers

In social perspective, the symbolic meaning of innovative work behavior and how it has given impact on individual's image have been highlighted. The reasons why individuals engage in innovative behavior activities are either these activities will enhance their expected positive image within organisation or they avoid innovative behavior activities if these activities do not conform to organisation or group norms [26]. Besides that, since innovation is a risky behavior and no guarantee of success, the future consequences maybe detrimental to individual's image. Thus, it is important for this current study to enlighten that innovative work behaviors can positively influence individual's career success in such ways.

Furthermore, in the country context, it also interesting that Malaysia has transformed itself from a traditional agricultural economy to becoming an export-driven one which is characterized by high technology, knowledge-based and capital-intensive industries [27]. Malaysia has an interesting and fusion culture which represents a mixture of Malay, Chinese, Indian and other indigenous ethnicities. Therefore, there is a need to understand more about the cross-cultural dimension. Research conducted on German employees may not generalize to other populations with distinct national cultural contexts. Hence, the current study is relevance to extend the context of cross-cultural dimension within Malaysia context. Significantly, Dyke and Duxbury [10] conducted a study on subjective career success by measuring fulfilling work, financial rewards, recognition and authority but did not integrate other factors that would potentially provide more robust explanation of career success. Hence, the current study will focus on more selected predictors such as performance, advancement, self-development, financial security, job security, satisfaction, recognition, creativity, cooperation and contribution as well.
In a recent qualitative study conducted by Dries, Pepermans, and Carlier [28], a multidimensional framework of the criteria for career success was elicited based on the interviews among 22 managers from 5 Belgian organisations. These dimensions of subjective career success include performance, advancement, self-development, creativity, security, satisfaction, recognition, cooperation, and contribution. This study provides important evidence on the multiple components of career success. Therefore, researchers need more quantitative data on issue to examine the relationship of innovative work behavior and subjective career success.

\section{B. Hypothesis}

Ha1: There is a significant relationship between opportunity exploration and subjective career success

Ha2: There is a relationship between on idea generation and subjective career success

Ha3: There is a relationship between idea promotion and subjective career success

Ha4: There is a relationship between idea realization and subjective career success

Ha5: There is a relationship between reflection and their subjective career success

Ha6: Innovative work behavior (opportunity exploration, idea generation, idea promotion, idea realisation \& reflection) influence subjective career success

\section{LITERATURE REVIEW}

\section{A. Career Success}

Social Cognitive Career Theory developed by Lent, Brown, and Hackett in 1994 [29], encourages scholars to understand about how three interrelated aspects of career development: (1) how basic academic and career interests develop, (2) how educational and career choices are made, and (3) how academic and career success obtained. The theory found that a variety of concepts such as interests, abilities, values and environmental factors have affected career development.

According to Lent and Brown [30], SCCT was originally developed to address the role of background variables, self-efficacy, and outcome expectations in the development of vocational interest, career choice and work performance, as illustrated in [29, Fig .1]. Self-efficacy is about individual's personal belief on their capabilities to perform the actual behaviors. SCCT assumes that when people have the required skills and environmental support to pursue the activities, they are likely to become interested in, choose to follow and perform better in activities because they have strong of self-efficacy beliefs. Outcomes expectations are about the consequences of doing such particular behaviors or actions. 


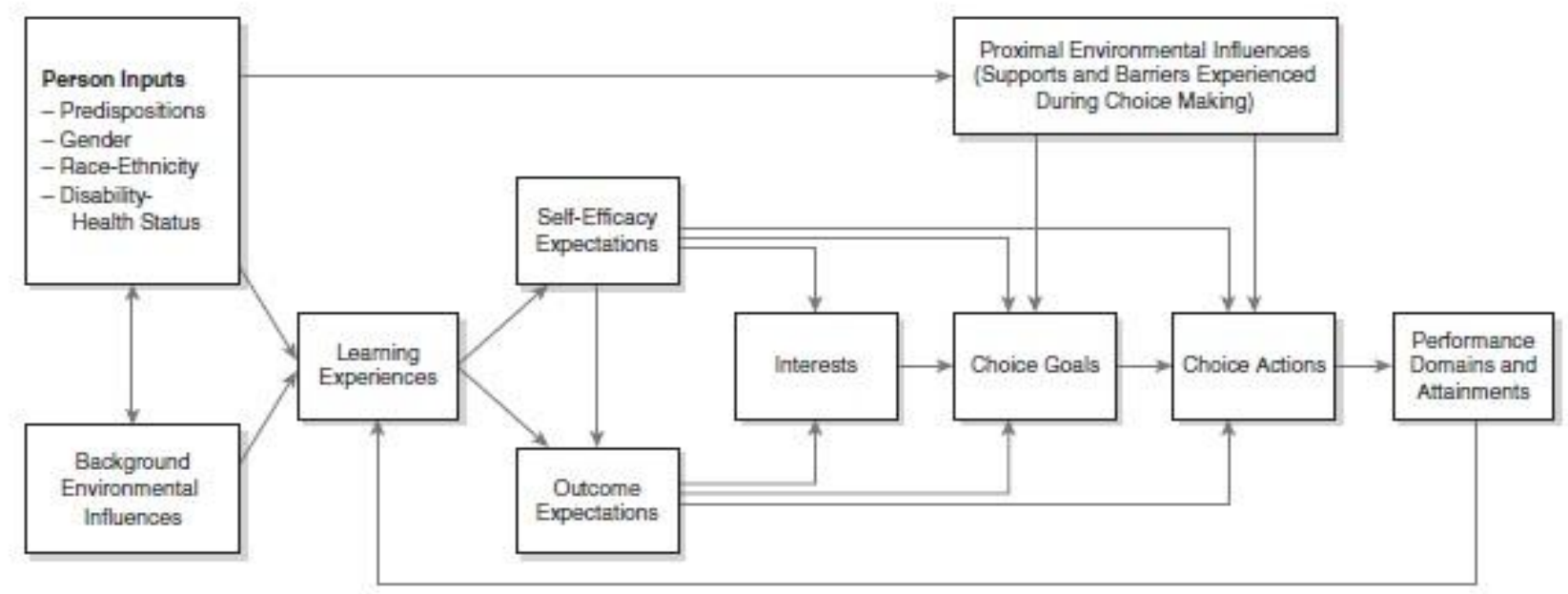

Fig 1: Development of career-related interest and choice based on Social Cognitive Career Theory. [29]

Personal goals refer to as people intentions to attain a certain level of performance or engage in certain activity.

SCCT represents a comprehensive theoretical framework for understanding vocational interest formation, career aspirations and choice behaviors, and career performance attainments. The central to SCCT is the assumption that two social cognitive mechanisms (self-efficacy beliefs and outcome expectations) figure prominently in interest formation and other important career outcomes. SCCT further posits that person inputs (predispositions) and background contextual affordances contribute to career-relevant learning experiences (performance accomplishments, vicarious learning, social persuasion, and physiological and affective states), which are considered experiential sources of corresponding self-efficacy beliefs and outcome expectations. Given that career success represents subsequent performance attainments, it can be understood in terms of SCCT, wherein career success would be affected by contextual influences for example in this study (subjective career success) through person inputs (innovative work behaviors).

Career success is a significant concept that helps to ensure individual's job satisfaction and their general well-being. Since the employee's success can be transferred translated? at the organisational level, it is also a critical concept for organisation as well [31]. Career success referred to "perceived or actual accomplishments that individuals have accumulated as a result of their employment" [32]. Career success is divided into two perspectives; objective and subjective. In earlier studies on career success, the focus was often on progression or advancement such as hierarchical status, in relation to salary and rate of promotion [33].

However, recent studies determined suggest? that the key success of the individual must be linked to the subjective standard such as working atmosphere among colleagues or job satisfaction [34]. Subjective career success represents individual feelings (self-evaluation) of accomplishment and satisfaction with their career [10]. Employees are more likely to report positive attitudes towards their work and their organisation when there is a fit between their definition of subjective career success and their career achievements [35]. The scholars suggested that by identifying ways to enhance employee subjective success experiences will help to enhance job satisfaction, commitment, and intention to stay at the organisation. It was included perceptions of intrinsic and extrinsic success through consideration of such matters as perceived personal progress, aspirations and comparisons in relation to colleague's advancement within organisation. With technological advances and globalization in today's working environment, career paths for individuals are less likely to have prescribed by the organisations [36]. Moreover, employees are likely to work for multiple organisations, managing and shaping their own careers in order to gain satisfaction and feeling engaged in meaningful work,[28]. rapidly changing of employment context does impact people's understanding of career development and career success Zhou et.al [37]. For example, due to downsizing of organisations some people are laid off and have to make next plan to do in their careers and some people have the flexibility to work on projects with multiple organisations. This is supported by Dries, Pepermans, and Carlier [28], people are likely becoming more boundaryless which means that career path are grow through project-based competency development but not bounded within specific organisations. The changing employment patterns makes people more concerned with the fulfilment of their own needs rather than organisational goals.

\section{B. Innovative Work Behaviors (IWB)}

Previous studies mentioned that innovative work behaviors contribute to positive outcomes, such as meaningful work and job autonomy [38], self-efficacy [39], work role performance [20], and psychological contract, job design and organisational justice [1]. A study by Cai et al. [38] indicates that employees' perceptions of meaningful work mediate the relationship between servant leaders and IWB. This mediating relationship is conditional on the moderating role of job autonomy in the path from servant leadership to meaningful work. The indirect effect of servant leadership on employee IWB via meaningful work exists only when job autonomy is high.

In addition, a study by $\mathrm{Ng}$ and Lucianetti [39] indicated that self-efficacy has a significant 
relationship with individual innovative behaviors and mediates the relationships to explain why employees have a strong motivation that can accomplish tasks through their innovative endeavors. A study conducted in Tianjin, China among 848 of employees revealed that high innovative behavior, self-efficacy and colleague solidarity can improve career success [23]. The results demonstrate the innovative behavior had a positive effect on career success through self-efficacy. Results indicated employees with high self-confidence and self-worth, they are likely to achieve successful outcomes when they have innovation awareness and implemented it in their workplace. Messman and Mulder [2], provided the solid evidence for reliability and validity of the developed instrument for innovation work behavior. In addition, the findings show that employees tend to engage in IWB since they expect positive image gains. Furthermore, the willingness to engage in IWB depends on individual preferences Sulistiawan et al. [40].

\section{METHODOLGY/MATERIALS}

This study utilised a quantitative approach and used simple random sampling for its data collection. The population of this study comprises with 180 of employees working in private construction organisation at Kuching, Sarawak. Based on formula by Krejcie and Morgan [41], 123 of sample size are required for a population of 180 of employees. Innovative work behaviors (Opportunity exploration, idea generation, idea promotion, idea realization, reflection) was measured using items-scale developed by Messmann and Mulder [2].Also, Subjective Career Success (performance, advancement, self-development, creativity, financial security, job security, satisfaction, recognition, cooperation, contribution) was adopted from Dries, Pepermans, and Carlier [28].

\section{RESULTS AND FINDINGS}

\section{Hypothesis 1: There is significant relationship between opportunity exploration and subjective career success}

Table 1 revealed that there was a significant relationship between opportunity exploration and subjective career success, $r(123)=.559, p<.05$. Therefore, Ha1 is accepted. Being given opportunity to explore as the chance to learn new skills, growth and advancement does significantly have relationship with subjective career success [23]. This is due to once the employees have resources and power to accomplish their tasks, they can be stimulated and motivated to perform very well and better which will improve their performance. Increases of knowledge and skills in a job increase the innovative work behaviors too. Opportunity exploration allows employees to learn new advance way to perform their task and it will lead to organizational production and effectiveness. Employees in this organisation believe that only by keeping themselves well- informed and updated with the latest development in organisation will increase their subjective career success.
Table 1: Innovative Work Behavior (Opportunity exploration, idea generation, idea realization \& reflection) and Subjective Career Success

\begin{tabular}{lcc}
\hline Variables & $\boldsymbol{r}$ & $\boldsymbol{p}$ \\
\hline Opportunity Exploration & .559 & .000 \\
Idea Generation & .568 & .000 \\
Idea Promotion & .617 & .000 \\
Idea Realization & .664 & .000 \\
Reflection & .650 & .000 \\
\hline
\end{tabular}

Hypothesis 2: There is a significant relationship between idea generation and subjective career success

Based on Table 1, results show there was a significant relationship between idea generation and subjective career success, $r(123)=0.568, p<0.05$. Therefore, Ha2 is accepted. The result was consistent with the previous finding [20], which claimed that when employees help to generate ideas and support, it will enhance employee's personal performance. Employees try to recognize and understand work related problems by provide the meaningful ideas to solve the problems. It can be understood that, the more likely employees generating the creative ideas, the greater subjective career success they perceived.

Hypothesis 3: There is a significant relationship between idea promotion and subjective career success

Table 1 indicated that there was a significant relationship between idea promotion and subjective career success, $r$ $(123)=0.617, p<0.05$. Therefore, Ha3 is accepted. The result was consistent with the suggestion by Parker, Williams and Turner [42], which indicated that individuals who are willing and able to innovate, will extend their contribution beyond the scope of their job requirements. Innovative employees feel a strong personal commitment to particular ideas, and they are someone in an informal role that pushes a creative idea beyond the roadblock within the organisation. Employees choose to innovate because they believe that by contributing to others will lead to subjective career success.

Hypothesis 4: There is a significant relationship between idea realization and subjective career success

There was a significant relationship between idea realization and subjective career success, $r(123)=0.664$, $p<.05$. Therefore, $\mathrm{Ha} 4$ is accepted. The result of the finding was consistent with a study by De Jong and Hartog [43], which examined idea realization could enhance employee's self-development. When employees engaged in idea realization, they are likely to benefits organisation, team and individual as well. Since organisation involves trial and

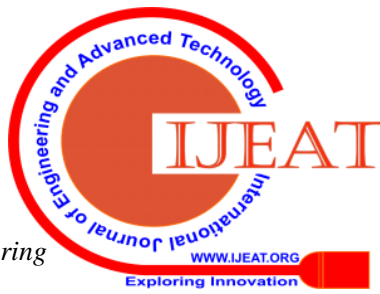


errors, success and failure, idea realization provides employees to try out the ideas into practices even though they will face the failure. From the failure experience, it will allow employees to keep improving themselves by learning and develop be better in future

Hypothesis 5: There is a significant relationship between reflection and subjective career success

There was a significant relationship between reflection and subjective career success, $r(123)=.650, p<.05$. Therefore, $\mathrm{Ha} 5$ is accepted. The result was consistent with the previous studies [44], [45], which found that reflecting on ideas, strategies, activities and outcomes contributes to the entire process of innovation development as well as employee's professional performance. When employees reflecting the outcomes at present activities, they are able to enhance their knowledge and skills for comparable future activities. The ability to complete task will giving them satisfaction towards employees and their good work will get the great recognition from others. Therefore, by doing reflection on what they do, it will impact positively on their subjective career success.

Hypothesis 6: The best dominant predictor(s) that influence subject career success

Table 2: Result of Multi-Linear Regression (stepwise) between Innovative work behaviors and Subjective Career Success

\begin{tabular}{lcccc}
\hline Variables & $\boldsymbol{b}$ & Beta & $\boldsymbol{t}$ & $\boldsymbol{p}$ \\
\hline Constant & 0.937 & & & \\
Idea Realization & 0.304 & 0.350 & 3.320 & 0.001 \\
Opportunity Exploration & 0.221 & 0.232 & 2.939 & 0.004 \\
Reflection & 0.257 & 0.240 & 2.211 & 0.029 \\
\hline$F=42.654$ & & $R=0.720$ & & \\
Sig- $F=0.000$ & & $R^{2}=0.518$ & \\
\hline
\end{tabular}

In order to find the best predictor that influence subjective career success, multiple linear regression test (Stepwise) have been utilized. The result from Table 2 shows that there are three predictors of "DV" were significant and a good fit with $F(3,119)=42.654, p=0.000$. The $R^{2}=0.518$ indicated that $51.8 \%$ of the variation "subjective career success" is explained by the idea realization (IR), reflection (RE), and opportunity exploration (OE) predictors. Results indicate that idea realization is the highest significant predictor contributed to subjective career success follow by reflection and opportunity exploration. Throughout the reflection process, it is allows employees to learn from the past experience and improve it to accomplish future tasks [2]. Thus, it is important for organisation to give more attention to the above selected predictor in designing innovative work behaviors strategy in order to increase employee's subjective career success.

\section{CONCLUSION}

The findings of this study have a number of important implications for future practice. The measurement instruments used in this study can be used by managers, supervisors and HRD practitioners to recognize and assess innovative work behaviors among employees. For instance, the measurements can help assist in employee's selection processes as well as for organisational evaluation purposes [2]. Furthermore, a measure of innovative work behaviors can be used to identify innovative employees, to understand how and when employees are innovative, ways to give them supportive feedback on their ideas and ultimately, foster the innovation development itself.

This study provides suggestion to the practitioners to provide an environment that support innovation in order to enable employees generating and apply innovative ideas and methods to practice. Such support will enhance employee's motivation and engage them in the organisation.

\section{Limitation}

The study of innovative work behaviors in this paper was limited only to opportunity exploration, idea generation, idea promotion, idea realization and reflection. Thus, other dimensions of innovative work were not being explored.

\section{Future Research}

Based on this study, several suggestions were being provided for future researchers. A comparative study can be performed across different industries and areas of work. It would be interesting to compare the findings across different occupations. A qualitative study should be conducted to provide qualitative aspects of human perception and the questionnaire items should be translated using bilingual language to minimize the culture variation issue.

\section{REFERENCES}

[3] J. J. Dy Bunpin, S. Chapman, M. Blegen, and J. Spetz, "Differences in innovative behavior among hospital-based registered nurses," JONA J. Nurs. Adm., vol. 46, no. 3, pp. 122-127, Mar. 2016

[4] C. k. Prahalad and V. Ramaswamy, "The new frontier of experience innovation," MIT Sloan Manag. Rev., vol. 44, no. 4 pp. $12-18,2003$.

[5] A. Smale et al., "Proactive career behaviors and subjective career success: The moderating role of national culture," $J$. Organ. Behav., vol. 40, no. 1, pp. 105-122, Jan. 2019.

[6] S. Elmas-Atay, "Work value fit and subjective career success: The moderating role of work engagement," Int. Rev. Manag. Mark., vol. 7, no. 3, pp. 113-120, 2017.

[7] K. M. Shockley, H. Ureksoy, O. B. Rodopman, L. F. Poteat, and T. R. Dullaghan, "Development of a new scale to measure subjective career success: A mixed-methods study," J. Organ. Behav., vol. 37, no. 1, pp. 128-153, Jan. 2016.

[8] T. W. H. Ng and D. C. Feldman, "Subjective career success: A meta-analytic review," J. Vocat. Behav., vol. 85, no. 2, pp 169-179, Oct. 2014.

[9] A. E. Abele, D. Spurk, and J. Volmer, "The construct of 
career success: measurement issues and an empirical example," Zeitschrift für Arbeitsmarktforsch., vol. 43, no. 3, pp. 195-206, Jan. 2011.

[10] L. Dyke and L. Duxbury, "The implications of subjective career success," Zeitschrift für Arbeitsmarktforsch., vol. 43, no. 3, pp. 219-229, Jan. 2011.

[11] E. Hennequin, "What 'career success' means to blue- collar workers," Career Dev. Int., vol. 12, no. 6, pp. 565-581, Oct. 2007.

[12] K. Lucas and P. M. Buzzanell, "Blue-collar work, career, and success: occupational narratives of Sisu," J. Appl. Commun. Res., vol. 32, no. 4, pp. 273-292, Oct. 2004.

[13] L. Arokiasamy, M. Ismail, A. Ahmad, and J. Othman, "Predictors of academics' career advancement at Malaysian private universities," J. Eur. Ind. Train., vol. 35, no. 6, pp. 589-605, Jul. 2011

[14] M. Ismail and M. Ibrahim, "Barriers to career progression faced by women," Gend. Manag. An Int. J., vol. 23, no. 1, pp. 51-66, Feb. 2008

[15] M. Ismail and R. M. Rasdi, High-flying women academics: A question of career mobility. Subang Jaya, Selangor, Malaysia: Pelanduk Publications, 2006.

[16] W. F. Dailey, J. A. Morris, and M. A. Hoge, "Workforce development innovations with direct care workers: Better jobs, better services, better business," Community Ment. Health J., vol. 51, no. 6, pp. 647-653, Aug. 2015.

[17] R. W. Lent and S. D. Brown, "Social cognitive career theory in a diverse world," J. Career Assess., vol. 25, no. 1, pp. 3-5, Feb. 2017.

[18] H. Abdullah, A. M. M. Salleh, M. S. Muda, and K. Omar, "A proposed modeling framework on innovative work behavior among employees in the Malaysian Islamic banking industry," Eur. J. Bus. Mangement, vol. 8, no. 28, 2016.

[19] M. N. Masrek, S. A. Noordin, N. I. Yusof, and S. M. Shuhidan, "The effect of job design on innovative work behavior," Int. J. Mech. Eng. Technol., vol. 8, no. 8, pp. 311-323, 2017.

[20] C. T. Leong and A. Rasli, "The relationship between innovative work behavior on work role performance: An empirical study," Procedia - Soc. Behav. Sci., vol. 129, pp. 592-600, May 2014.

[21] D. Spurk and A. E. Abele, "Synchronous and time-lagged effects between occupational self-efficacy and objective and subjective career success: Findings from a four-wave and 9-year longitudinal study," J. Vocat. Behav., vol. 84, no. 2, pp. 119-132, Apr. 2014

[22] R. M. Rasdi, T. N. Garavan, and M. Ismail, "Understanding proactive behaviors and career success: Evidence from an emerging economy," Organ. Mark. Emerg. Econ., vol. 2, no. 04, pp. 53-71, 2011

[23] X. Dan, S. Xu, J. Liu, R. Hou, Y. Liu, and H. Ma, "Innovative behavior and career success: Mediating roles of self-efficacy and colleague solidarity of nurses," Int. J. Nurs. Sci., vol. 5, no. 3, pp. 275-280, Jul. 2018.

[24] K. D. Kaur and V. Gupta, "The impact of personal chracteristics on innovative work behavior: An exploration into innovation and its determinants amongst teachers," Int. J. Indian Psychol., vol. 3 , no. 3,2016

[25] A. Widmann and R. H. Mulder, "Team learning behaviors and innovative work behavior in work teams," Eur. J. Innov. Manag., vol. 21, no. 3, pp. 501-520, Aug. 2018.

[26] F. Yuan and R. W. Woodman, "Innovative behavior in the workplace: The role of performance and image outcome expectations," Acad. Manag. J., vol. 53, no. 2, pp. 323-342, 2010.

[27] MIDA, "Malaysian Investment Development Authority," 2009 Accessed on: July 3 2019. [Online]. Available: https://www.mida.gov.my/home/

[28] N. Dries, R. Pepermans, and O. Carlier, "Career success: Constructing a multidimensional model," J. Vocat. Behav., vol. 73, no. 2, pp. 254-267, Oct. 2008.

[29] R. W. Lent, S. D. Brown, and G. Hackett, "Social cognitive career theory," in Career choice and development 4, 2002, pp. 255-311.

[30] R. W. Lent and S. D. Brown, "Social cognitive model of career self-management: Toward a unifying view of adaptive career behavior across the life span.," J. Couns. Psychol., vol. 60, no. 4, pp. 557-568, 2013.

[31] T. W. H. Ng and D. C. Feldman, "Affective organizational commitment and citizenship behavior: Linear and non-linear
[32] S. L. D. Restubog, P. Bordia, and S. Bordia, "Investigating the role of psychological contract breach on career success: Convergent evidence from two longitudinal studies," J. Vocat. Behav., vol. 79, no. 2, pp. 428-437, Oct. 2011.

[33] A. E. Abele and D. Spurk, "The longitudinal impact of self-efficacy and career goals on objective and subjective career success," J. Vocat. Behav., vol. 74, no. 1, pp. 53-62, Feb. 2009.

[34] P. D. Converse, J. Pathak, A. M. DePaul-Haddock, T. Gotlib, and M. Merbedone, "Controlling your environment and yourself: Implications for career success," J. Vocat. Behav., vol. 80, no. 1, pp. 148-159, Feb. 2012.

[35] A. L. Kristof-Brown, R. D. Zimmerman, and E. C. Johnson, "Consequences of individuals' fit at work: A meta-analysis of person-job, person-organization, person-group, and person-supervisor fit," Pers. Psychol., vol. 58, no. 2, pp. 281-342, Jun. 2005.

[36] D. T. Hall and D. E. Chandler, "Psychological success: When the career is acalling," J. Organ. Behav., vol. 26, no. 2, pp. 155-176, Mar. 2005.

[37] W. Zhou, J. Sun, Y. Guan, Y. Li, and J. Pan, “Criteria of career success among chinese employees," J. Career Assess., vol. 21 no. 2, pp. 265-277, May 2013.

[38] W. Cai, E. I. Lysova, S. N. Khapova, and B. A. G. Bossink, "Servant leadership and innovative 2ork behavior in chinese high-tech firms: A moderated mediation model of meaningful work and job autonomy," Front. Psychol., vol. 9, Oct. 2018.

[39] T. W. H. Ng and L. Lucianetti, "Within-individual increases in innovative behavior and creative, persuasion, and change self-efficacy over time: A social-cognitive theory perspective.," J. Appl. Psychol., vol. 101, no. 1, pp. 14-34, 2016.

[40] J. Sulistiawan, N. Herachwati, S. Dwi Permatasari, and Z. Alfirdaus, "The antecedents of innovative work behavior: The roles of self-monitoring," Probl. Perspect. Manag., vol. 15, no. 4, pp. 263-270, Dec. 2017.

[41] R. V. Krejcie and D. W. Morgan, "Determining sample size for research activities," Educ. Psychol. Meas., vol. 30, no. 3, pp. 607-610, Sep. 1970.

[42] S. K. Parker, H. M. Williams, and N. Turner, "Modeling the antecedents of proactive behavior at work.," J. Appl. Psychol. vol. 91, no. 3, pp. 636-652, 2006.

[43] J. de Jong and D. den Hartog, "Measuring innovative work behavior," Creat. Innov. Manag., vol. 19, no. 1, pp. 23-36, Mar. 2010.

[44] A. Müller, B. Herbig, and K. Petrovic, "The explication of implicit team knowledge and its supporting effect on team Processes and technical innovations," Small Gr. Res., vol. 40 , no. 1 , pp. 28-51, Feb. 2009.

[45] M. van Woerkom, "The concept of critical reflection and its implications for human resource development," Adv. Dev. Hum. Resour., vol. 6, no. 2, pp. 178-192, May 2004.

\section{AUTHORS PROFILE}

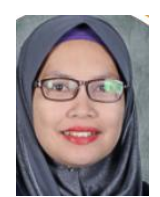

Dr. Nur Fatihah Abdullah Bandar is a Senior Lecturer at Human Resource Development Programme in the Faculty of Cognitive Sciences and Human Development, Universiti Malaysia Sarawak. She was a Research Assistant at Asia -Europe Institute, Universiti Malaya (2010-2013) before joining the Universiti Malaysia Sarawak in 2014. She graduated with a Bachelor of Science in (Human Development) in 2006 and Master degree in Human Resource Development from Universiti Putra Malaysia in 2010 and her doctorate $(\mathrm{PhD})$ in Social Sciences and Humanities (Quality of Life) from Universiti Malaya in 2015. For the most part of her career, her research is geared towards quality of life, quality of work life, career development, disability studies, happiness studies and well-being. She won a few Best Paper Award and Best Presenter Award at conferences and actively publish in indexed and non-indexed publication Since 2014, her teaching portfolio are statistics for Social Sciences for postgraduate students, and work-life balance, career development, Introduction to Human Resource Development and Human Development Psychology, 
Organizational Development for undergraduate level. She also involved in MOOC development for Introduction to Human Resource Development. She has been invited to become a trainer for SPSS Workshop for (Basic and Intermediate) level for postgraduate students and also for the general public. related to the area of education, work-life balance and retirement planning and preparation in organization. She has presented and published papers locally and internationally. She is also has involved in consultancy projects for public sector in Sarawak

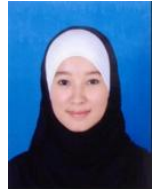

Fatin Adibah binti Malek graduated with Bachelor Degree of Science in Human Resource Development in 2015 from University Malaysia Sarawak (UNIMAS). Currently pursuing her Masters degree program in Human Resource Development and is expected to graduate from the program by October 2019. Her master research focuses on 'The Relationship Between Innovative Work Behaviors and Subjective Career Success Among employees in Selected Private organisation in Kuching, Sarawak.

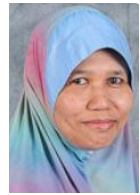

Dr. Zaiton Hassan is an Associate Professor of Human Resource Development Program, Faculty of Cognitive Sciences and Human Development, Universiti Malaysia Sarawak, Malaysia. She received her PhD (Organizational Psychology) from University of South Australia, Adelaide, Australia in 2010, Master of Science (Organizational Psychology) from University of Hertfordshire, United Kingdom and bachelor's degree in human development from Universiti Putra Malaysia. Her PhD thesis Work-Life Balance among Malaysian Employees had been selected for inclusion in the overall compendium of activities for the World Health Organization (WHO) Global Plan of Action 2008-2012 for UniSA WHO collaborating center for occupational health. She has published more than 30 papers (indexed and non-indexed) in the area of Work Life Balance as well as other human resources related topic. She is an editor for one book on Contemporary Research on Work Life Balance in Malaysia (2016) published by Universiti Malaysia Sarawak Press and contributed book chapters in psychosocial factors at work published by Springer (2014). She served as reviewer for indexed journals in human resource, management related field and had won a few Best Paper Award at national and international conferences. Her current research interests include work-life balance, religiosity, flow at work and voice and silence. Recent consultancy project includes establishment of childcare center at workplace (2017-2020), organizational culture (2017-2020) and change (2019-2020) in private and public sector in Sarawak, Malaysia.

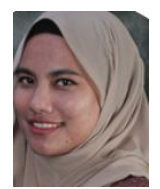

Nik Norsyamimi binti Md Nor currently holds a position as a University Lecturer in University of Malaysia Sarawak (UNIMAS). She attended the University of Utara Malaysia (UUM) for her Bachelor of Science in Human Resource Management and Mater of Science in Management in year of 2006. Before her tenure in education field, she has been served as a research assistant in UUM and a human resource practitioner in financial private company for several years. She also has collaborated with other Faculty members in writing project work and book write up in the area of work life balance, organizational behavior, and soft skills development and currently towards the Labor Studies. Based on her research interest background, her passion is to explore in depth on the turnover/ turnover intention issues in Malaysia perspective. Most of research papers published in several conferences/journals was emphasized on turnover and work life balance. Some of the research works was in National Research Grant (Research Acculturation Collaborative Effort-RACE), Internal Research Grant (Short Grant Scheme-SGS) and Fundamental Research Grant Scheme (FRGS). The future exploration in human resource development and sustainability in aquaculture in Sarawak setting will be her next project for a research contribution.

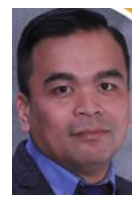

Rekaya Vincent Balang is a Senior Lecturer at Department of Nursing, Faculty of Medicine and Health Sciences, UNIMAS $\mathrm{He}$ is also a registered nurse with the Malaysian Nursing Board since 2001. He obtained his BSc (Hons.) in Nursing from Universiti Malaysia Sarawak (UNIMAS). He holds a Master of Nursing from University of South Australia and a $\mathrm{PhD}$, focusing on nursing practice and professionalism, from University of Huddersfield, UK. He also holds a Post Graduate Diploma in Teaching and Learning from UNIMAS. He started his career as a staff nurse in various settings such as Trauma OT and Mental Health. His research interests are nursing practice and issues, professionalism in nursing, nursing education and research, mental health, medical surgical and other pertinent health sciences. He has presented and published papers locally and internationally.

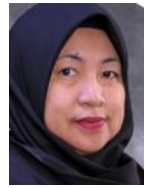

Dr Surena Sabil is currently a Senior Lecturer at Departmen of Human Resource Department, Faculty of Cognitive Sciences and Human Development, Universiti Malaysia Sarawak (UNIMAS). She was conferred Doctor of Philosophy (Public Management) by University of Malaya in 2013, Master of Business in Quality Management from University of Western Sydney in 2002 and Bachelor Science in Human Development from Universiti Putra Malaysia in 1997. Currently she is the Dean of Faculty of Cognitive Sciences and Human Development, Universiti Malaysia Sarawak. To date she has published more than 20 articles in local and international journals and conference proceedings related to her area as well as supervise $\mathrm{PhD}$ and Master by research students. Her current research interest is on work-family balance/career development, women development and quality management. She is also involved in consultancy projects for public and private sector in Sarawak, Malaysia.

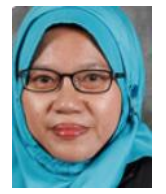

Dayang Kartini binti Abang Ibrahim received her Bachelor of Education in TESL at University of Exeter, United Kingdom in 1999. She started her Master degree in the field of Human Resource Development and graduated in 2007. She started working in Ministry of Education as a teacher from 1999 until 2004. In 2005, she worked in Kuching District Education office as the language officer. She resigned from Ministry of Education and started to work in University Malaysia Sarawak in 2010. Currently, she is pursuing her study in Phd at UPM in the field of Human Resource Development. Most of her research and publications are 